\title{
The Volumes of the Royal Medical Society of France, 1776-1793: a Window into Innovation, Patronage and Experimentation
}

\section{by Daniel Hickey}

\begin{abstract}
In 1776, Doctors Vicq d'Azyr and Joseph de Lassone founded the Royal Medical Society of France and that same year the new Society began publishing an annual volume of news of medical interest, obituaries on the deaths of outstanding doctors and surgeons, articles on new medicine and drugs, on new operations as well as reflecting on the causes of different diseases and illnesses. Between 1776 and 1793 , ten of these volumes were published under the title Histoire de la Société Royale de Médecine: histoire et mémoires. The Osler Library of the History of Medicine possesses four of them. Breaking with the tradition of Galen and with the diagnoses based on bookish knowledge, the members of this group favoured experimentation, the dissection of corpses and the close observation of the symptoms of the sick and the dying. This article looks at two aspects of their work: first it examines the goals and the structures of the Society that published the volumes and second, it analyses the organization and the types of articles published in the annual volumes.
\end{abstract}

\section{RESUMÉ}

Les médecins Vicq d’Azyr et Joseph de Lassone ont fondé la Société royale de médecine en 1776 et aussitôt la nouvelle société a commencé à organiser la publication annuelle d'un volume de nouvelles d'intérêt médicales. Il devrait comporter les avis de décès des médecins et chirurgiens de renom, les articles sur des médicaments et drogues qui venaient d'être mis sur le marché, les interventions particulièrement innovatrices et les réflexions sur les causes de différentes maladies et épidémies. Entre 1776 et 1793, dix de ces volumes sont apparus sous le titre, Histoire de la Société Royale de Médecine: histoire et mémoires. La bibliothèque Osler de l'histoire de médecine détient quatre de ces volumes. Les articles des membres de ce groupe rompent avec la tradition de Galien et avec les diagnostics fondés sur les connaissances livresques. Ils favorisent l'expérimentation, la dissection des cadavres et l'observation des symptômes présentés par les maladies et les mourantes. Cet article étudie deux aspects de ces travaux: d'abord, il décrit les buts et les structures de la Société elle-même et second, il analyse l'organisation et les types d'articles publiés dans les volumes annuels.

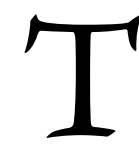
he Osler Library of Medical History is perhaps the best example of a repository of rare and valuable sources in the field of the history of medicine for Canada and the United Kingdom, but it also has strong resources for France. Several years ago, I came across several volumes of the invaluable Histoire de la Société Royale de Médecine: histoire et mémoires, an annual publication of the late $18^{\text {th }}$ century Royal Medical Society of France, a learned society created by several doctors and public health specialists. The Osler Library purchased its four volumes of the Histoire de la Société Royale de Médecine: histoire et mémoires in 1981 from the Librairie Alain Brieux in Paris. ${ }^{1}$ From its very beginning the Royal Medical Society that published the volumes had a triple objective. First, it sought to renew the practice and teaching of medicine by recruiting new, young medical men and researchers. Second, it wanted to "professionalize" the medical expertise of practicing physicians and surgeons by providing them with information on new operations, experimentations and medication. Finally, it worked to maintain and to reinforce its links to the royal court and to the lucrative contracts it received through favouritism and patronage. This article will concentrate on the Society and its annual volumes in two sections. Initially, it will analyze the origins of the Society and its founding members who organized and published the volumes. Secondly, it will look at the contents of the volumes, trying to show their links to the three objectives the directors sought to promote.

\section{THE ORIGINS AND THE FOUNDERS OF THE SOCIETY}

Initially, the Royal Medical Society was formed by a number of medical men and health specialists who had served together to combat a major outbreak of epizooty, or cattle plague in 1774-75. Controlleur-général Turgot appointed Vicq d'Azyr, the future head of the Royal Medical Society, to deal with the epidemic. Vicq d'Azyr decided to go well beyond the traditional methods of segregating sick animals in times of such an epidemic. He set up sanitary cordons to divide the affected area into different categories: disease-free 
areas were to impose precautionary hygienic measures, the threatened areas were submitted to a more drastic regime of drugs and disinfectants, and the center of the outbreak was to be cordoned off and the sick animals were to be slaughtered and buried in quicklime with the government offering token remuneration to the farmers. ${ }^{2}$ The royal court saw the work of Vicq d'Azyr and his colleagues in dealing with this outbreak as a model of the application of new sanitary practices.

After dealing with the 1774 outbreak, Vicq d'Azyr together with his colleague Joseph de Lassone, set out to found the new Royal Medical Society. They used many of the contacts they had made during the 1774-75 epidemic to establish the Society in 1776 and to obtain a charter for the group in 1778. The Society they set up met twice a week to listen to and to debate papers and reports in the field of medicine and public health presented by its members and correspondents. In 1776, the first year of its activities, the Society began preparing the first of the volumes found in the Osler Library. The eventual collection included the papers presented at Society meetings, obituaries, research notes, memoirs and reports on the organization's activities. The annual volumes were actually published a year or two after their compilation such that the 1776 volume was published in 1779 . In all, the Royal Society published 10 of these volumes, the last of which appeared in 1789, the year that marked the beginning of the French Revolution. The Society was broken up in 1793, the year Louis XVI was sent to the guillotine.

Among the goals of this organization were the promotion of new teaching methods and new ways to practice medicine. According to the American historian Caroline Hannaway, the program set out by the men behind the Society would eventually bring them into conflict with the directors of the Paris Faculty of Medicine, who accused them of trying to appropriate too much power over the teaching and practice of medicine in France. ${ }^{3}$ However, the Society has been credited with playing a major role in the eventual establishment of the Paris Clinic. ${ }^{4}$ The Paris Clinic represented a major change in the perception and practice of medicine in France. Based upon empiric investigation, it sought to brush aside the traditional "bookish" medical knowledge derived from Galen or Paracelsus in which doctors used their reading and personal judgement to diagnose their patients one by one based on the descriptions of their pains and problems. Instead, with the French Revolution and the creation of the École national de medicine in 1794, medical authorities adopted new techniques of anatomic-clinical investigation. Doctors and surgeons sought to use the hospitals as laboratories to observe the sick and to teach their students. To confirm their diagnoses, they used their experience in dissecting corpses, their close observations of the symptoms of their sick patients and their accumulated medical statistics. A whole new cohort of doctors and surgeons practiced this new type of medicine, among them, Marie-François Bichat (1771-1802), JeanNicolas Corvisart (1755-1821), Pierre Louis (1781-1826) and René Théophile Laennec (1781-1826). ${ }^{5}$ One of the bases of this new scientific medicine was the abandoning of the long tradition of separating the work and training of doctors and surgeons. They were both incorporated into the new École national de medicine and into the hospital structure. In many ways, this new type of medicine followed closely a document that Vicq d'Azyr, secrétaire perpétuel of the Royal Medical Society, had submitted to the National Assembly in 1790. It was the draft of a law to govern the practice of medicine in France and it proposed the convergence of medical and surgical practice and training, the extension of hands-on experience for students through the examination of the sick and the dying as well as the dissection of cadavers. The new programme also proposed to set up an Academy of medicine to promote the advancement of medical science. ${ }^{6}$ In 1794 the framework of several of these proposals was effectively incorporated into the charter of the École national de santé, one of the principal building blocks of the Paris Clinic.

As with all types of innovation, however, the Royal Society was a mix of old and new. Its members were torn between their tendency as children of the Enlightenment to turn the page on old methods and at the same time their desire to remain attached to the benefits they derived from the old society, from the patronage of the royal court and the Crown and from the sponsored "research" and the contracts distributed through favouritism. Vicq d'Azyr, originally from Normandy, was a researcher in anatomy at the Paris Faculty of Medicine and he held a position as consulting physician to the King's brother, the count of Artois. Even more important was Joseph de Lassone, principal physician to Queen Marie Antoinette. Through his position he maintained close ties to the royal court. Lassone co-presided over the Society with Joseph Lieutaud, Dean of the Paris Medical Faculty. However, the role of Lieutaud was mainly symbolic. Caroline Hannaway found that he had never attended a meeting of the group and that he died in 1780. In fact, after his passing, the Paris Faculty of Medicine became one of the principal opponents of the Royal Society and to its attempts to renew the teaching and practice of medicine in France. ${ }^{7}$

Who actually made up this new Society? According to the patent letters of 1778 , the general assembly was to be composed of thirty ordinary associates (associés ordinaires) who were to elect the president and vice-president. They were also to name one of their members as secrétaire perpétuel, although it was noted in the patent letters that they "had named and confirmed Sieur Vicq d'Azyr to continue to exercise that function." And he held the position right up to the dissolution of the Society. In addition, the patent letters specified that twenty of the thirty associates were to be medical doctors, residents of Paris and members of the Paris Faculty of Medicine. The other ten were to be chosen without restriction by the associés. In addition to the ordinary associates, the document noted that the Society was to be made up of twelve associés libres, residents of Paris, sixty 
associés regnicoles coming from the French provinces and another sixty associés étrangers coming from outside France. ${ }^{8}$

At the same time that this structure appears relatively transparent and open to new, younger members, there were clauses that allowed the directors to maintain control over the organization, clauses that were regularly cited by critics like the Faculty of Medicine. An example of these clauses is article $\mathrm{V}$ stipulating that:

The Society will proceed by vote to elect the secrétaire perpétuel, the associés ordinaries, libres, regnicoles and étrangers: \& it will present the Society with the person who appears most apt to fill the vacant position; preferring, however, that the positions of the associés be and remain filled by those who presently occupy them: knowing their zeal, experience and capacity, we [the directors] have confirmed them in their positions... ${ }^{9}$

It is clear that the positions of Lassone and Vicq d'Azyr were not to be surrendered and that they surrounded themselves with friends and collaborators from the 1774 work on the epizootic outbreak.

The first six associés, Antoine Laurent de Jussieu, Claude Caille, Jean de Lalouette, Dieudonné Jeanroi, Michel Augustin Thouret and Jean Jacques Paulet were all friends, close to Vicq d'Azyr. The first three were young medical doctors who had just been named regents of the Paris Faculty of Medicine. Jeanroi and Thouret had almost finished their medical degrees and Paulet was a medical doctor from Montpellier who had worked on the 1774 epidemic. The five doctors added in July 1776 were more experienced: Michel Bouvart, Pierre Poissonier and his brother Antoine, Charles Lorry and Pierre Maloet all had important medical practices in Paris. With their nominations the directors appear to have tried to give added credibility to the Society. Other important medical men appeared in subsequent lists although their functions had not been among those named in the patent letters. Antoine Fourcroy, a protégé of Vicq d'Azyr and a student at the Faculty of Medicine, held the position of secretary. Another category absent from the patent letters, the associés adjoints, appeared in October 1776. Among the new men named in that category were Pierre Mauduyt de la Varenne, a specialist on electromagnetic applications in medicine, Charles Andry, a researcher on effects of rage, Charles Saillant on epilepsy, Henri Tessier on botany, and Jean Colombier, one of the principal architects of hospital policy and administration.

Clearly, this core of researchers, administrators and medical men was built up around the friends and associates of Lassone and especially of Vicq d'Azyr. They were generally engaged in experimental research and uncontaminated by what they termed the "old methods" of the Faculty of Medicine. Other supporters of the movement, politicians and royal officials surrounded these men and partisans of the Enlightenment were added as associés libres. Among them there was the Duc de la Rochefoucault, one of the leading promoters of enlightenment research; Jacques Necker, the Minister of Finance; the Count of Vergennes, a Minister and former Secretary of State; Poulletier de la Salle, a Maitre de requêtes; Montigny, the President des Treasurers of France. All of these men provided key support for the Society within the inner circles of the royal government. In the category of associés étrangers, the group also sought to increase its credibility and prestige. Among the foreigners selected, were Benjamin Franklin from the United States, Dr Tissot from Lausanne, Switzerland and Dr William Hunter from England.

\section{THE ORGANIZATION AND CONTENTS OF THE VOLUMES}

Right from the first volumes of the Histoire de la Société Royale de Médecine: histoire et mémoires, the Society had a clear objective of renewing the practice and teaching of medicine as can be seen by the selection and recruitment of young medical men and researchers. At the same time, it sought to remain attached to the favoritism of the Court and to the contracts accorded through favoritism and patronage. These two directions can be observed in the research projects undertaken by the Society, in the reports read before the members at the regular meetings, in the prizes regularly awarded to young researchers and in the approval of new medications and sources of mineral water.

From the first volume, Vicq d'Azyr, who was responsible for the publication, announced the twelve different sections to be treated in each tome (see Table 1). The treatment of these themes was to be divided it into two sections-Histoire and Mémoires. In the first of these sections he published news articles, death notices, comments on published works, meteorological observations and short articles and notices concerning forthcoming publications. The second section of each volume was to treat the same types of subjects through much longer research reports treating the different stages of each project, the experiments conducted and the results obtained. The length of these articles frequently attained a hundred pages. The Society also sponsored a competition for medical researchers who were asked to read their papers before the Society. The directors of the organization proposed questions to its members, associates and correspondents who delivered papers on the suggested themes. The best papers received prizes varying from 300 to 600 livres and they were to be published in the upcoming volume.

The articles, notices and projects published each year provide us with a window from which to observe the objectives of the Society in each of its areas of expertise. I have selected four of these areas for in-depth examination. 


\section{Reinforcing the perception of the medical profession}

First and foremost among the objectives of the Society was the desire to reiterate and to reinforce the common values that should be shared within the medical profession. Vicq d'Azyr used the obituaries of deceased medical men to promote the professionalization of his colleagues. He described in hagiographical terms the lives of those he judged to have been outstanding medical men and proposed them as role models for their colleagues. The French historian, Daniel Roche, has studied a corpus of 56 of these obituaries: in 45 cases the deceased were medical doctors, in 3 cases doctors of surgery, in 3 other cases simple surgeons and in the remaining three cases apothecaries or chemists. ${ }^{10}$ In several of his long eulogies (25-30 pages), Vicq d'Azyr tried to build up an idealistic image of the physician of the Enlightenment and whenever he could, he attributed to his deceased colleagues the qualities that he associated with the modern medical man. Education was consistently valorized-the colleges they frequented were indicated for 37 of the 56 men and for 45 of them he noted the University attended. ${ }^{11}$ In the course of their training, he underlined the importance of clinical practice and the integration of other disciplines in their studies (physics, chemistry and the humanities). In the case of Linné, it was noted that as a teacher, he integrated physics lessons into the medical courses he taught at Uppsala and in the obituary for Haller, the note emphasized that he had taught at Tübingen, Leyde and Bâle where the curriculum reflected a "modern" approach. ${ }^{12}$ Hospital teaching was particularly favored in these eulogies and in the case of the Irish doctor MacBride, Vicq d'Azyr noted the importance of practice and observation in the formation of a physician,

"...it was clearly in the hospices where a wise administration cares for the poor and suffering that young doctors and surgeons can find useful lessons... It is there that one can learn to read in the eyes, in the facial traits, in the gestures, in the comportment of the sick and to distinguish those signs that the observer can see without being able to describe them, signs that cannot be found in books, and which it is so important not to mistake."13

Other issues of the time were treated in the obituaries. Vicq d'Azyr emphasized whenever possible the denunciations of charlatans and empirical "doctors" by the deceased. Writing about Dr Girod, inspector of public health in FrancheComté, he noted that Girod, "scared and dispersed the hoards of inept charlatans who...flood the countryside and sell hope and poison to the gullible peasant." ${ }^{14}$ Altogether, he found similar denunciations for 12 of the 53 deceased colleagues. Finally, on the question of the devotion of these men, Vicq d'Azyr contended that three-quarters of them died of "fatigue" or of the "dangers" linked to their profession. Writing about

\section{Table 1. The proposed divisions of each volume of Histoire de la Société Royale}

1. The activities of the Society during the year.

Reports on the proceedings of the two public sessions.

Résumés of the conferences held.

Prizes accorded for the best presentations.

Grants received for applied research, such as the origins of different epidemics.

Obituaries of members who died during the year.

Observations and reviews of books, reports and publications submitted by members.

All changes in the statutes and regulations of the Society.

2. Weather observations for the year compiled from reports submitted by members and correspondents.

3. Descriptions of the topography of different regions, cities, towns and villages with details concerning the impact of various factors on health of inhabitants.

4\&5. Reports on human or animal epidemics in different regions, towns, prisons or hospitals.

6. Epizootic illnesses.

7. Analyses of the nature or treatments of acute or chronic illnesses.

8. Contagious illnesses.

9. Discussions of anatomy and of illnesses identified from dissecting cadavers.

10. Biochemical medicine: the analysis of new medicine and mineral water sources.

11. Botany and natural history.

12. The study of physics applied to medical treatments. 
Dr Maret of Burgundy, he noted that the doctor had left for Fresne-Saint-Mamès to treat several patients suffering from an epidemic fever and upon his arrival in the village he himself came down with the fever, however, according to Vicq d'Azyr, Maret continued to care for his patients, "a contagious doctor who visited his patients and tried to bring them back to life even as he himself was dying." ${ }^{15}$

\section{Demonstrating the research and innovation of the profession}

The second major objective of the Society was to demonstrate the serious research and innovation of the modern medical profession. The men associated with the Society sought to turn the page on past medical practices as was evident in the formal presentation of their papers in the annual volumes. Methodology was particularly important and each paper read at their meetings contained a long description of the research methods used. Among others, Charles Lorry applied this approach in his paper on human obesity, its effects on the body, its vices and the diseases it could cause. Delivering this research before his colleagues on 7 September 1776, he began by setting out his approach,

"Let us leave to the professors who lecture their disciples on the task of examining and refuting the hypotheses that have created public opinion from Hippocrates to today. For us, we have the obligation to examine and to learn by observing... It is within this context that I will expose what my observations over a period of several years have taught me concerning the effects of fat in the human body as a secondary cause of morbidity, either directly because of the mass of fat or indirectly because of the effects it can produce on other humours..." ${ }^{16}$

The pages of the Histoire de la Société royale are full of observations and research papers that follow the methods explained by Lorry. Each of the volumes contained sections in which doctors, surgeons and veterinarians explained in detail the different steps they had taken in trying to cure rare physical disorders, proposing new experimental treatments and illustrating new types of procedures. As Brockliss and Jones have noted, the Society opened the door to experimentation with new empirical approaches for both humans and animals. ${ }^{17}$ The cases included in these sections extended from major surgeries to items like the veterinary Daubenton's remedies for treating sheep disorders, including recommendations on the best places to carry out bloodletting on sheep, suggesting bleeding the animal below the cheek bone (see Illustration 1). ${ }^{18}$ Among other contributions is an article by Dr Hannequin, a surgeon in Charleville, on a Caesarian section that he performed "with success" on a 28 year old woman. His test follows the methodology prescribed by the Society as he explains step by step the evolution of his patient from 31 August, the date of his intervention through the healing process up to 24 September. Describing the operation, Hannequin noted that he "made an incision eight inches long with his scalpel on the right-hand side of the lower stomach. The peritoneum was opened with the aid of a crenulated scalpel which was also used to open the uterus in which a seven inch incision was made...revealing the [dead] child who was extracted from the womb, a very large male baby." ${ }^{19}$ Hannequin's daily observations note the vital signs of the patient during her recovery, her pains and the healing of the wound. It should be noted that the "success" of the interventions should be understood in the context of the period, an intervention made without anesthesia and generally made only in the case of extracting dead babies.

Inoculation was another subject of predilection for the members of the Society and Dr Girod, who was eulogized by Vicq d'Azyr in the 1786 volume, had contributed an article on the success of the inoculation campaign against smallpox in Franche-Comté. It appeared in the 1780 volume that was published in 1785. Girod noted that in the village of Millau, Pelet, an "enlightened" doctor, carried out his first inoculation on an orphan girl and the success of the intervention led to the inoculation of 229 other villagers between 20 March and 20 June and "none of them died." ${ }^{20}$ Such descriptions of new prophylactic methods and techniques were legion in the volumes of the Histoire de la Société royale. Among other interventions, they described the actions taken against aneurysms, scurvy, rage, ergotism, military fever, dropsy and kidney stones.

\section{Analyzing the influence of climate and topography}

The Royal Medical Society was born as an offshoot of the 1774 epizootic epidemic and the Crown obviously wanted the group to continue its research into the possible causes of such outbreaks. From the time of Hippocrates it was believed that polluted air led to contagion and it was only with the coming of bacteriological studies and particularly the work of Pasteur that the development of the study of internal organisms like bacteria, micro-organisms and viruses changed the direction of medical studies. Medicine at the time of the Enlightenment still stuck to the theory that outside forces like polluted air, humidity and climate caused sickness and epidemics. ${ }^{21}$ To study these phenomena, the volumes of Histoire de la Société royale contained long and detailed data on climate and topography, seeing them as a cause of sickness and epidemics.

In the second section of each volume, Father Cotte, an associé regnicole, published the meteorological observations conscientiously submitted by correspondents scattered throughout France: daily indications of temperature, barometer readings, periods of sunshine, humidity, rainfall, wind direction and velocity. Alongside these tables, the correspondents indicated the five or six sicknesses most 
Mém. de la Soc. Rle de Méd. Artnée. 2776 . Pag.326. Pl. I.

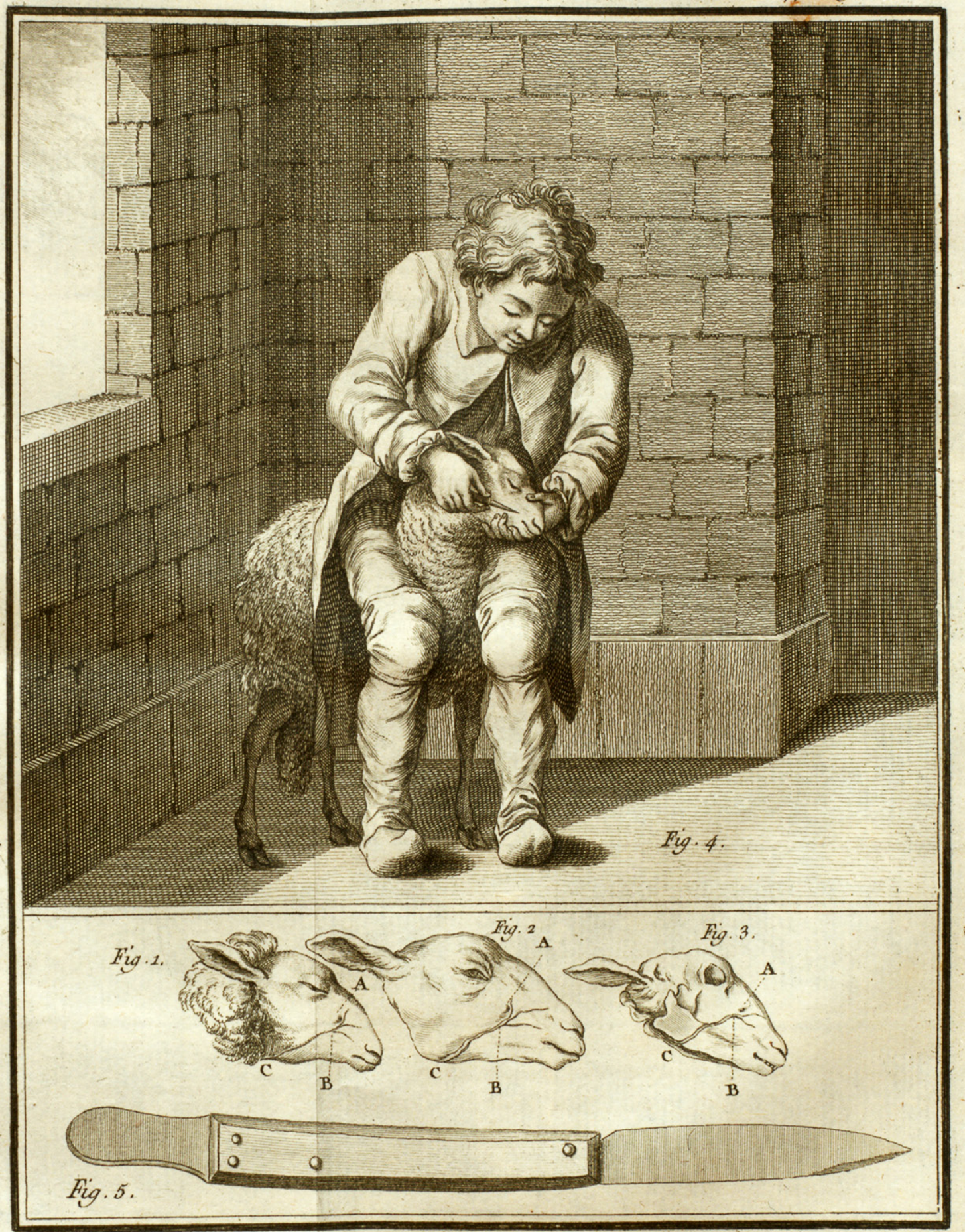

Fossier del.

Baron Sculp.

Illustration 1. Remedies for treating sheep disorders. Recommendations of places to carry out blood-letting [Histoire de la Société royale de médecine : histoire et mémoires, 1776. Paris : Philippe-Denis Pierres, 1779, 316-17]

Reproduced by permission of the Osler Library of the History of Medicine, McGill University 
frequently treated during the month along with notes explaining how these illnesses first appeared, their symptoms, their progression, the seriousness of their impact, the treatments given to patients and their morbidity. Often the correspondents illustrated their observations with concrete cases.

The third section of each volume continued on this theme with detailed micro-studies on selected towns and regions where the authors elaborated on the interaction between sickness and climate, topography, demographic density, diet and agricultural production. This section was obviously a follow-up on the type of study that Vicq d'Azyr had prepared in his 1774-75 work on the epizootic epidemic in Languedoc and it constituted an extension of Abbé Cotte's tables. It was clear that the directors of the Society felt that such studies responded to societal needs and at the same time they made a favorable impression on Crown officials. This is corroborated in a note in volume IV that the government and several of the members of the Society had contributed 4,000 livres to encourage such work. ${ }^{22}$

Here too, the Society's correspondents submitted articles that reflected the beliefs of the pre-Pastorian period to combat epidemics. One of their foreign associates Antoine Ribeiro Sanchès, who had been chief physician to the Empress of Russia, contributed an article on Russian steam baths as a means of combating smallpox, pleurisy, chest and kidney disorders. He even proposed a blueprint of what he considered to be the ideal plan for building a steam bath (see Illustration 2). ${ }^{23}$

This concentration on epidemics can also be seen in the subjects studied in the essay competitions held by the Society. The directors of the organization often proposed questions relating to the cause of epidemics. In 1776, the first year of its existence, the judges asked for papers establishing "...the relation between epidemic illnesses and other concurrent illnesses that struck at the same time and place." Seeing that the papers submitted were not up to the standards of the Society, the judges turned them all down and they repeated the question in a subsequent competition. Finally, in 1781, they accorded a prize of 600 livres to Dr Raymond of Marseilles for his text on the subject, read before the group at their March 6 meeting. In his work on the activities of the Society, the late French historian, Jean-Pierre Peter saw the organization's research in linking illness and epidemics to the environment and to the lack of municipal and regional improvements in health and sanitation as one of the major contributions to the medicalisation of French society. ${ }^{24}$

\section{Approving new drugs and mineral water sources}

Just as with their work on climate and topography, the dealings of the Society with new drugs and mineral water sources responded to the preoccupation of both the public and the Crown with these questions. During the $18^{\text {th }}$ century, there was a marked increase in the popularity of both new drugs and new mineral water sources. However, many of these remedies were considered to be precisely the type of quack medicine that the Society associated with "Charletanism". In the interest of public health, the Society lobbied the Crown to obtain the right to inspect and to approve the new drugs to be sold and new the mineral water to be commercialized in the Kingdom. This was the most controversial of the group's activities. It was a very profitable initiative on the part of the Society, but it led the group into considerable difficulty trying to maneuver between the marketplace, its patrons and its clients. According to detractors, like the Paris Faculty of Medicine, d'Azyr and Lessone sought these powers in order to obtain pay-offs for themselves and for their organization. ${ }^{25}$ In the 1778 patent letters creating the Society, article 10 gave them the right to "examine new internal and external remedies... [and to] order that none of the said remedies should be sold or distributed without the approval of the Society..." Article 12 extended these powers to the approval of mineral water. ${ }^{26}$

In order to carry out these "responsibilities" the $11^{\text {th }}$ and $12^{\text {th }}$ chapters of each of the volumes of the Histoire de la Société royale published analyses of new remedies and sources of mineral water that had been submitted to the Society for approval. In these chapters the members examined and reported on new remedies based on products like cinchona, Epsom salts or ipecacuanha as well as providing analyses of numerous new mineral water sources. This policing of new remedies led to decisions that were often questioned and Vicq d'Azyr had to justify these powers in the 1777-78 volume of Histoire de la Société. ${ }^{27}$ Trying to portray the standards of the Society as professional and demanding, Vicq d'Azyr argued in 1790 that the Society had approved only 4 of the more than 800 drugs and remedies that they had tested. In fact, the archives of the organization tell us a different story, indicating that the group had approved 10 such submissions and temporarily authorized another 34 for a period of four or five years. ${ }^{28}$ But, even the approved remedies were often controversial. En 1774, the correspondents of the Society in Bordeaux wrote to Vicq d'Azyr to denounce a certain Mathis who was selling "anti-venereal enemas" saying that the Society had approved his product. Vicq d'Azyr replied that, in effect, Mathis had received the right to sell his product. ${ }^{29}$ In Languedoc, Constant Chiarini accompanied a circus selling a tonic that wasn't anything more than a vegetable broth and he too said that the Royal Society had approved the tonic. Under questioning, Chiarini admitted to having obtained his authorization from Vicq d'Azyr's valet for 66 livres. $^{30}$

These four volumes reveal a discourse in favor of innovation within the French medical establishment emanating from the period of the Enlightenment and preceding the Paris Clinic. The sessions dedicated to discussions of the morbidity of obesity, the campaigns of inoculation, or the epizootic 

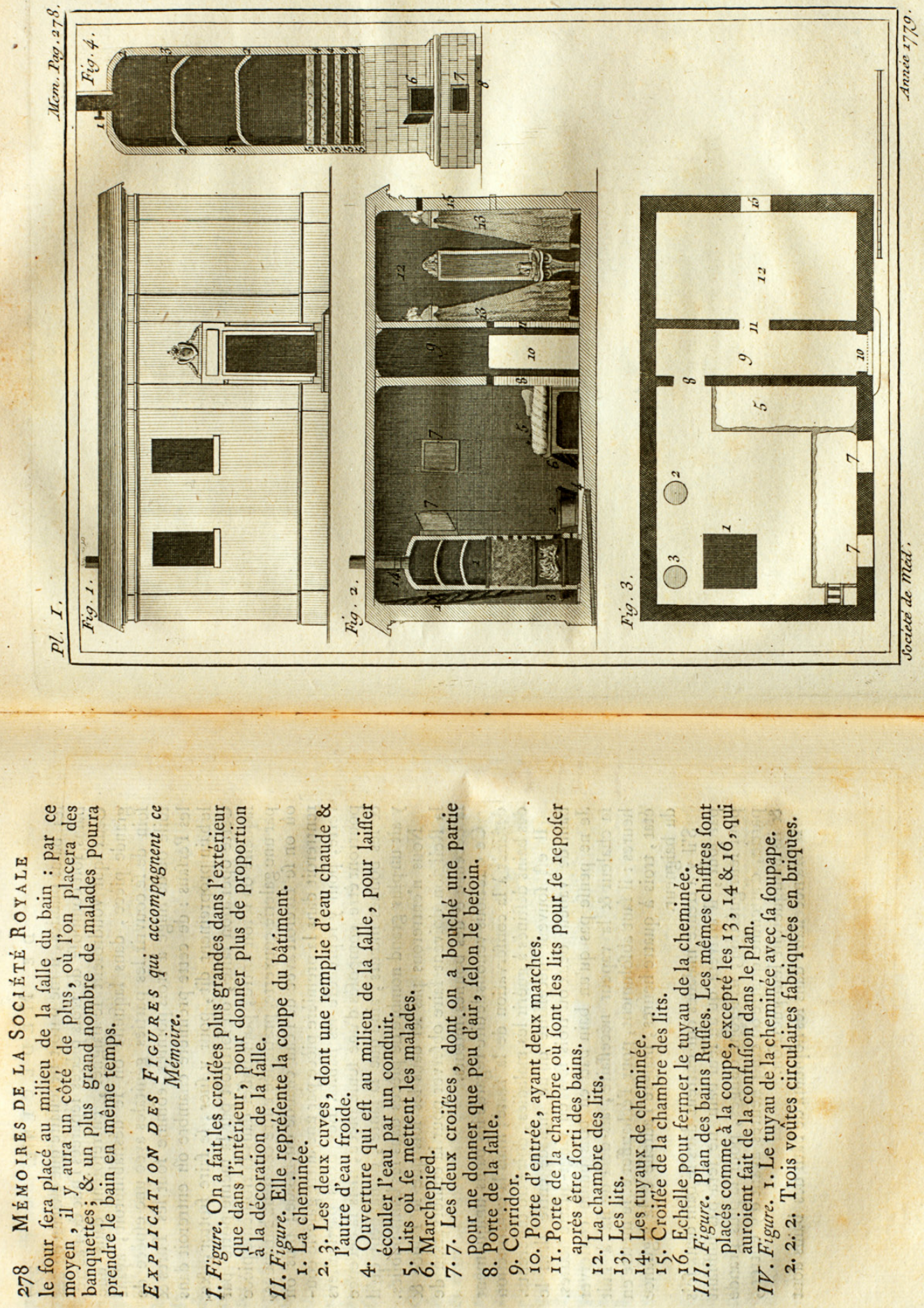
outbreaks certainly enhanced the standing of the Society in the field of public health. At the same time, this work reinforced the group's position with its patrons in the royal court and among the many supporters of Enlightenment research. Medical men were one of the principal groups targeted by the work of the Society. After all, doctors, surgeons and medical researchers were the principal readers of the volumes and the obvious strategy of Vicq d'Azyr was to use obituaries of the "stars" of the profession to create and/ or to reinforce a common mythology and set of values for the medical profession. On a more serious note, it was certainly hoped that country doctors and small town practitioners would learn from the long and detailed explanations of how to perform new types of medical or sanitary interventions. The other principal targets for the Society were the royal court and the patrons of Enlightenment research. The articles on the influence of climate and the regular meteorological observations were clearly meant to show the public health aspects of their work. This, together with the group's experience in dealing with epidemics among animals or human beings was meant to solidify the standing of the Society with its patrons and supporters.

In going through the pages of these volumes, one is struck by the fact that the group is trying to leave behind what they see as centuries of "bookish" medical practice. Their articles are rarely based on previous medical work. There is a new direction behind what Corvisart would call "the clinical gaze", looking beyond the standard medical diagnoses derived from the symptoms described by the patient. ${ }^{31}$ The pages of these volumes describe how meticulous physical examinations, data derived from the dissection of corpses or the observation of natural phenomena were becoming the new basis for analysis, diagnoses and medical hypotheses. It would be up to the Paris Clinic to take the next steps to legislate in these fields, abandoning the Old Regime patronage system in favor of new governmental initiatives in the fields of medicalization and public health.

\section{ENDNOTES}

${ }^{1}$ Histoire de la Société royale de médecine : histoire et mémoires, 1776. Paris : Philippe-Denis Pierres, 1779. Histoire de la Société royale de médecine: histoire et mémoires, 1777-78. Paris : Philippe-Denis Pierres, 1780. Histoire de la Société royale de médecine : histoire et mémoires, 1779. Paris : P. Théophile Barrois, 1782. Histoire de la Société royale de médecine : histoire et mémoires, 1780-81. Paris : chez Théophile Barrois, 1785.

${ }^{2}$ Lawrence Brockliss and Colin Jones. The Medical World of Early Modern France. Oxford: Clarendon Press, 1989, 744-45.

${ }^{3}$ Caroline Hannaway. "Medicine, Public Welfare and the State in $18^{\text {th }}$ century France: The Société Royale de Medicine de Paris (1776-93)." PhD thesis, Johns Hopkins University, 1974, 131.

${ }^{4}$ Erwin Ackerknecht. Medecine at the Paris Hospital, 1794-1848. Baltimore: Johns Hopkins University Press, 1967. Michel Foucault. The Birth of the Clinic, trans by A.M. Sheridan Smith. London: Tavistock, 1973.

5oceline Chabot, Daniel Hickey and Martin Pâquet, Autour de la médicalisation: Perspectives historiques, pratiques et représentations (XVe-XXe siècles). Québec : Presses de l'Université Laval, 2012, 3-8.
'Vicq d'Azyr. "Nouveau plan de constitution pour la médecine en France." Enquêtes et documents relatif à l'enseignement supérieur, 1789-1803. Edited by A. de Beauchamp. Médecine et Pharmacie 28 (1888), 1-158. Also see Brockliss and Jones, 810-11.

${ }^{7}$ Hannaway, 131. Brockliss and Jones add that Lieutaud was very sceptical of the role that the Sociéte was trying to acquire under the direction of Lassone and d'Azyr, especially regarding their attempts to control over approval of new medication and medical treatments as well as over the approval of new sources of mineral water, see Brockliss and Jones, 764.

${ }^{8}$ Lettres patentes du Roi, portant établissement d'une Société Royale de Médecine, données à Versailles au mois d'août 1778, printed in Histoire et mémoires de la Société Royale de Médecine, 1776. Paris : Philippe-Denys Pierre, 1779, 20-21.

${ }^{9}$ Ibid., 21. (This and the following translations are mine.)

${ }^{10}$ Daniel Roche. "Talent, raison et sacrifice: l'image du médecin des Lumières d'après les éloges de la Société royale de médecine (1776-89)." Annales (E.S.C.), 32, 5 ( 1977), 866-67.

${ }^{11} \mathrm{Ibid}, 870-71$.

${ }^{12} \mathrm{Ibid}, 874$.

13“Éloge de Dr MacBride." Histoire de la Société royale de médecine, 1777-78, 54.

14 "Éloge de Girod." Histoire et mémoires de la Société royale de médecine, 1782. Paris : Philippe-Denis Pierres, 1786, 63.

${ }^{15}$ Daniel Roche, 882.

${ }^{16}$ Lorry. "Sur la graisse considérée dans le corps humaine, sue ses effets, ses vices et sur les maladies qu'il peut causer," Histoire de la Société royale de médecine, 1776, 97.

${ }^{17}$ Brockliss and Jones, 575-78.

${ }^{18} \mathrm{M}$. Daubenton, "Mémoire sur les remèdes les plus nécessaire aux troupeaux," Histoire de la Société royale de médecine, 1776, 312-20.

${ }^{19}$ Hennequin. "Opération césarienne." Histoire de la Société royale de médecine, 1777-78, 236-41

${ }^{20}$ Girod. "Mémoire sur l'inoculation." Histoire de la Société royale de médecine, 1780-81, 231. Also see Girod. "Observations relatives à l'inoculation de la petite vérole." Histoire de la Société royale de médecine, 1777-78, 185-93.

${ }^{21}$ Georges Vigarello. Histoire des pratiques de santé. Le sain et le malsain depuis le Moyen Age. Paris: Seuil, 1993, 180-91.

${ }^{22}$ Histoire de la Société royale de médecine, 1780-81, 27.

${ }^{23}$ Antoine Ribeiro Sanchès, "Sur les bains de vapeur de Russie," Histoire de la Société royale de médecine, 1779, 233-80.

${ }^{24}$ Jean-Pierre Peter. "Une enquête de la Société royale de médecine : Maladies et malades à la fin du XVIIIe siècle." Annales (E.S.C.), 22, 4 (1967), 711-51. Jean-Pierre Peter. "Aux sources de la médicalisation, le regard et le mot : le travail des topographes médicales." Population et cultures : Études réunis en l'honneur de François Lebrun. Edited by Alain Croix. Rennes : Presses de l'Université de Bretagne, 1989, 61-83.

${ }^{25}$ Lawrence Brockliss and Colin Jones also note that the Joseph Lieutaud, the King's physician and the nominal co-president of the Sociéte was very skeptical of the role assumed by the Sociéte royale in approving new medicine, medical treatments and mineral waters. See Brockliss and Jones, 764.

${ }^{26}$ Lettres patentes du Roi portant établissement d'une Société royale de médecine, Versailles, August 1778. Histoire de la Société royale de médecine, 1776, 22-23.

${ }^{27}$ Histoire de la Société royale de médecine, 1777-78, 10-12.

${ }^{28}$ Brockless and Jones, 772.

${ }^{29} \mathrm{Ibid}, 777$.

${ }^{30} \mathrm{Ibid}, 776-77$.

${ }^{31}$ Jean Nicolas Corvisart. "Preface" to the French translation of Léopold Auenbrugger. Nouvelle méthode pour reconnaitre les maladies internes de la poitrine. Paris, 1808 cited in Foucault, 122. 